Link article (Style APA): Halian O. I. (2021). Development patterns of the idea of personal agency and its implementation in the domestic educational practice of the $\mathrm{XX}^{\text {th }}$ century. Insight: the psychological dimensions of society, 5, 82-99. DOI: 10.32999/2663-970X/2021-5-6

Link article (Style DSTU 8302: 2015): Halian O. I. Development patterns of the idea of personal agency and its implementation in the domestic educational practice of the $\mathrm{XX}^{\text {th }}$ century. Insight: the psychological dimensions of society, 2021, 5, 82-99. DOI: 10.32999/2663-970X/2021-5-6

UDC 159.923.2:37.04

\title{
Development patterns of the idea of personal agency and its implementation in the domestic educational practice of the $\mathrm{XX}^{\text {th }}$ century
}

\section{Закономірності розвитку ідеї суб'єктності особистості та її реалізації У вітчизняній освітній практиці ХХ століття}

Received: February3, 2021

Halian Olena Ivanivna

Doctor of Pedagogy,

Professor of the Department

of Practical Psychology

Drohobych Ivan Franko

State Pedagogical University, Ukraine

halyane@ukr.net

ORCID 0000-0001-6070-9669
Accepted: May 25, 2021

\author{
Галян Олена Іванівна \\ доктор педагогічних наук, \\ професор кафедри практичної психології \\ Дрогобицький державний педагогічний \\ університет \\ імені Івана Франка, Україна \\ halyane@ukr.net \\ ORCID 0000-0001-6070-9669
}

\begin{abstract}
The purpose of the article is to represent changes in the understanding and implementation of the idea of personal agency of schoolchildren inherent in Ukrainian pedagogical discourse and actual practice of education institutions in the $\mathrm{XX}^{\text {th }}$ century. The above has forwarded the research to the following areas of concern: to establish the dynamics of a cognitive-creative process of generating and implementing the idea of agency given its philosophical, psychological, educational-political and pedagogical-technological context; to create a general infographic periodization of the development of the idea of agency based on comparing profiles of agency of schoolchildren of the studied period in a particular territory. Methods: To solve the research tasks, the author has used interpretational methods, particularly genesis one, that has made it possible to conclude about the development patterns of the idea
\end{abstract}

\begin{abstract}
Анотація
Метою статті $\epsilon$ репрезентація закономірних для українського педагогічного дискурсу і реальної практики діяльності закладів освіти XX століття змін в осмисленні та втіленні ідеї суб'єктності особистості учнів. Означене зорієнтувало дослідження на такі проблемні напрямки: встановити динаміку когнітивно-креативного процесу генерування та впровадження ідеї суб'єктності з урахуванням іiі філософського, психологічного, освітньо-політичного та педагогічно-технологічного контексту; створити загальну інфографіку періодизації розвитку ідеї суб'єктності на основі зіставлення профілів суб'єктності учнів досліджуваного періоду на окресленій території. Методи. Розв'язування дослідницьких завдань передбачало використання інтерпретаційних методів, зокрема, генезного, що уможливило висновки про
\end{abstract}




\section{Development patterns of the idea of personal agency and its implementation in the domestic educational practice of the $\mathrm{XX}^{\text {th }}$ century}

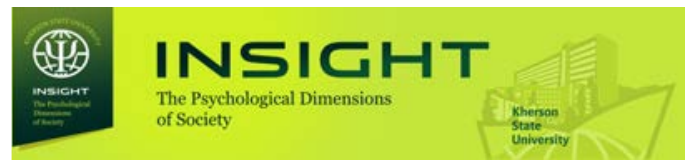

of personal agency in the scientific-pedagogical discourse and introduced models of schoolchildren's education and upbringing; the modelling of the progress of the idea contributes to finding out the logic of its generating and transformation; a discourse-analysis for the identification of a socio-cultural dimension of the agency-related issues in the pedagogical ideas of the $\mathrm{XX}^{\text {th }}$ century; a comparative analysis to compare agency profiles in the defined periods. Results. Development patterns and introduction of the idea of a pupil's personal agency are studied within three dimensions: philosophical-psychological (methodological), the coordinate system of which is a civilizational type of personality (classical, modern, postmodern), and society (monarchical, industrial, democratic, information technology); educational and political, which is rendered on the axes of state reforms and pedagogical (including innovative) schools; pedagogical-technological covering, on the one hand, the content-process aspect of educational, developmental and pedagogical effect of a teacher and, on the other hand, an effective-evaluation aspect of the pedagogical influence represented by new formations of a pupil and changes in the pedagogical situation. Conclusions. A logic of the development of a child's agency in the domestic educational theory and practice of the $\mathrm{XX}^{\text {th }}$ century is rendered under the framework of shaping visions of agency as a cultural demand of the socio-historical formation, a generic feature of a representative of the civilization, a component of pedagogical ideal, competencies and a specified level of a child's development (a social demand for education), a note on his social role as a means of involving the child into the educational process, an opportunity for his self-realization. The key trends of the development of the idea of a pupil's agency concern the changes in socio-historical formations and cultural-psychological type of community and psychological type of a personality belonging to a specific epoch, worldviews and educational paradigms, theoretical substantiation of a new pedagogical thesaurus and technology innovations in education institutions.

Key words: agency, theoretical-applied knowledge, logic of idea development, determination and transformation of idea, agency profile, educational process.

\section{Introduction}

The current transitivity and globalization processes determine a need to study the issues related to themanifestation of personalagencyinall the areas of life activities. Thus, under the emerged conditions, a man can't realize only his adaptive закономірності розвитку ідеї суб'єктності особистості в науково-педагогічному дискурсі та впроваджених моделях навчання і виховання учнів; моделювання розвитку ідеї, щоб встановити логіку їі генерування та трансформації; дискурс-аналізу для виявлення соціокультурного виміру суб'єктнісної проблематики в педагогічних ідеях XX століття; порівняльного аналізу з метою зіставлення профілів суб'єктності у виокремлених періодах. Результати. Закономірності розвитку та впровадження ідеї суб'єктності особистості школяра розглянуто в трьох площинах: філософсько-психологічній (методологічній), системою координат якої є цивілізаційний тип особистості (класична, модерна, постмодерна) та суспільства (монархічне, індустріальне, демократичне, інформаційно-технологічне); освітньо-політичній, розгорнутій на осях державних реформ та педагогічних (зокрема, і новаторських) шкіл; педагогічно-технологічній, яка охоплює, з одного боку, змістово-процесний бік навчального, розвивального та виховного впливів педагога, та 3 іншого - результатно-оцінний бік педагогічного впливу, представлений новоутвореннями учня та змінами педагогічної ситуації. Висновки. Логіка розвитку ідеї суб'єктності учня у вітчизняній освітній теорії та практиці XX століття представлена в межах формування уявлень про суб'єктність як культурну вимогу суспільно-історичної формації, типову ознаку представника цивілізації, складову виховного ідеалу, компетентностей і нормативного рівня розвитку школяра (суспільний запит освіті), припис щодо його соціальної ролі, як засіб залучення учня до освітнього процесу, можливість його особистісної самореалізації. Провідні тенденції розвитку ідеї суб'єктності учня стосуються змін суспільно-історичних формацій і культурно-психологічного типу спільноти та психологічного типу особистості відповідної епохи, світоглядних позицій та освітніх парадигм, теоретичного обгрунтування нового педагогічного тезаурусу та технологічних інновацій у закладах освіти.

Ключові слова: суб'єктність, теоретико-прикладне знання, логіка розвитку ідеї, детермінація та трансформація ідеї, профіль суб’єктності, освітній процес.

\section{Вступ}

Транзитивність сьогодення та процеси глобалізації детермінують необхідність дослідження питань, пов'язаних із проявом суб'єктності особистості в усіх сферах

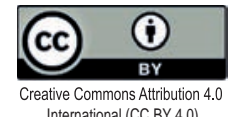


function - he must become an active participant of the social transformations and self-creation. The present requires expanding opportunities to realize one's individuality and stipulating the importance of personal changes meeting new conditions in which the human potential is unlocked. In this context, the idea of personal agency seems relevant. That sort of approach gains a particular importance in the education system, which lays the foundation of agency, selfactivity and postulates the agency-based approach to education, upbringing and development of students of different ages.

A focus on the progressive changes in the educational environment is directly associated with an identification of benchmarks of the transformation of a pedagogical reality in which, in the author's opinion, the agency of the participants of the educational process may become a regulator of the scientific cognition. Being system-making, this category is a basis for the development of theoreticalmethodological aspects of many pedagogical concepts and paradigms. However, its details and a role in catalyzing the pedagogical potential of the education situation are interpreted ambiguously. By defining a pupil as a subject of training, education and evolution, his subjectoriented position is usually declared in the context of pedagogical interaction. In fact, he is an object of the pedagogical influence but, at the same time, he reserves the right to agency. Taking into account the beforementioned, a significant scientificapplied task involves justifying theoreticalmethodological fundamentals of development of the idea of personal agency, actual indices of its approbation in the educational practice and prospects for the implementation amidst modern challenges.

Therefore, the author associates a thorough study of the logic of shaping the idea of personal agency in a retrospective of the pedagogical thought and educational practice of the $X^{\text {th }}$ century with a necessity to consider the subject-oriented approaches elaborated in the scientific-methodological contributions of educators, psychologists, philosophers of that period to improve the current educational situation, which has a growing interest in a pupil's життєздійснення. Адже в умовах, що виникли, людина не може реалізовувати лише свою адаптивну функцію, вона повинна стати активним учасником суспільних перетворень та самотворення. Сьогодення вимагає не тільки розширення можливостей для розкриття індивідуальності особистості, але й зумовлює важливість ії самозмін відповідно до нових умов, у яких реалізується людський потенціал. У цьому контексті ідея суб'єктності особистості стає вельми доречною. Особливої актуальності такий підхід набуває в системі освіти, де закладаються основи суб’єктності, самоактивності та постулюється суб'єктний підхід до навчання, виховання й розвитку учнів різного віку.

Орієнтованість на прогресивні зміни в освітньому середовищі неодмінно пов'язана 3 визначенням основних орієнтирів трансформації педагогічної реальності, у якій, на нашу думку, регулятивом наукового пізнання може стати суб'єктність учасників освітнього процесу. Як системотвірна, ця категорія слугує основою для розроблення теоретико-методологічних аспектів багатьох педагогічних концепцій та парадигм. Однак її змістове наповнення та роль в активізації педагогічного потенціалу освітньої ситуації інтерпретується неоднозначно. Визнаючи учня суб'єктом навчання, виховання та розвитку, його суб'єкт-орієнтована позиція в педагогічній взаємодії зазвичай лише декларується. Реально він залишається об'єктом педагогічного впливу, водночас зберігає право на суб'єктність. 3 огляду на це значущим науково-прикладним завданням $є$ обгрунтування теоретико-методологічних засад розвитку ідеї суб'єктності особистості, реальних показників іiї апробації в освітній практиці та перспектив реалізації в умовах викликів сьогодення.

Відповідно, грунтовне дослідження логіки формування ідеї суб'єктності особистості в ретроспективі педагогічної думки та освітньої практики XX століття ми пов'язуємо 3 необхідністю врахування суб'єкт-орієнтованих підходів, розроблених у науково-методичних працях педагогів, психологів, філософів цього періоду, для вдосконалення сучасної освітньої ситуації, у якій зростає інтерес до

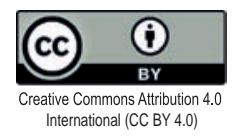


Development patterns of the idea of personal agency and its implementation in the domestic educational practice of the $\mathrm{XX}^{\text {th }}$ century

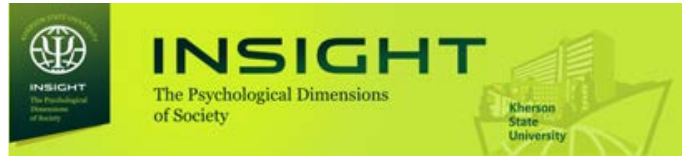

personality as a subject of cognition and activity, his motivation for self-regulated education. By analyzing the theoretical ground and performance of the tested models of implementation of the idea of agency in the domestic educational practice of the XXth century, the author strives to find out the general patterns which contributed to the development of visions of pupils' selfrealization in the educational environment, their involvement in the process of acquiring, as well as in the context which ensures the mentioned idea, i.e., its transpectivity.

The purpose of the research is to outline the general trends in the dynamics of the evolution of pupils' agency in the Ukrainian pedagogical discourse of the $\mathrm{XX}^{\text {th }}$ century and the practice of education institutions that is defined as a ground for the implementation of agency-oriented educational process under the modern conditions.

\section{Methods}

An interdisciplinary nature of the research has made it possible: a) to identify a unified scientific context of understanding a category of "pupil's agency" and agency profile; b) to arrange the available models of realization of the attributes of pupil's agency in the domestic scientific discourse and the educational practice of the $\mathrm{XX}^{\text {th }}$ century; c) to substantiate the determination of an idea-genesis of agency-related issues given its trigger, first, by a worldview in terms of an individual and society and, second, a sociohistorical background of the education reforms; third, conditions of organizing the educational process, a context of a pedagogical reality.

An ontological approach to the study of the phenomenon of agency has allowed specifying those attributive features which facilitate the identification of agency in the manifestations of a pupil of the $\mathrm{XX}^{\text {th }}$ century, scientific publications of the relevant period, and the worldview considerations which were extended to the educational practice.

A historical-scientific analysis has been aimed at systemizing and understanding of gnoseology of the category of "agency", its markers and their verification in the models of organization of the educational process, which особистості учня як суб’єкта пізнання та діяльності, його мотивування до саморегульованого навчання. Аналізуючи теоретичне підгрунтя та результативність апробованих моделей втілення ідеї суб'єктності у вітчизняній освітній практиці XX століття, ми прагнемо віднайти загальні закономірності, які сприяли розвиткові уявлень про самоздійснення учнів в освітньому середовищі, їх залучення до процесу засвоєння та той контекст, у якому означена ідея буде забезпечена, тобто її транспективність.

\section{Мета дослідження}

Метою статті є окреслення загальних тенденцій динаміки розвитку ідеї суб'єктності учнів в українському педагогічному дискурсі $\mathrm{XX}$ століття та практиці діяльності закладів освіти, що визнаємо підгрунтям для впровадження суб'єктнісно-орієнтованого освітнього процесу в умовах сьогодення.

\section{Методологія}

Міждисциплінарний характер дослідження дав змогу: а) визначити єдиний науковий контекст осмислення категорії «суб'єктність учня» та профілю суб'єктності; б) систематизувати наявні моделі реалізації атрибутів суб'єктності учнів у вітчизняному науковому дискурсі та освітній практиці XX століття; в) обгрунтувати детермінацію ідеєгенезисуб'єктнісної проблематики з огляду на їі спричиненість, по-перше, світоглядною позицією щодо особистості та спільноти, по-друге, суспільно-історичними передумовами освітніх реформ; по-третє, умовами організації освітнього процесу, контекстом педагогічної реальності.

Онтологічний підхід до дослідження феномена суб'єктності уможливив окреслення тих атрибутивних ознак, за допомогою яких суб'єктність ідентифікується в проявах школяра XX століття, наукових публікаціях досліджуваного періоду, та тих світоглядних міркуваннях, які екстраполювалися на освітню практику.

Історико-науковий аналіз спрямовано на систематизацію й осмислення гносеології категорії «суб’єктність», її маркерів та їх верифікацію в апробованих у вітчизняній освітній 
were approbated by the domestic educational practice. The acquired knowledge refers to the formulation of strategies meeting modern demands for the development of educational innovations, the part of which is an idea of selforganization of a subject of training, his ability to an effective self-actualization in such dimensions as education, mutual and self-education, improvement, mutual and self-improvement, development, mutual and self-development.

An application of interpretation strategies, comparative and discourse analysis has ensured the systematization of dynamic patterns in the profiles of agency of domestic schoolchildren of the $\mathrm{XX}^{\text {th }}$ century and the detection of a degree and character of the relations between determinants, which triggered the development and transformation of the idea of agency-based direction of the educational process to be viable and effective.

Quantitative estimation of an agency's manifestation is both an important and auxiliary tool of its diagnostics. Moreover, the category of "agency" originates from the understanding of internally aroused processes, the evaluation of which under standard criteria (upward or downward deviation) is incorrect. Analysis of psychological-pedagogical characteristics of a pupil mentioned in the scientific and educational-methodological publications (total: 137 sources) upon the defined criteria and indicators is the best option for the present research to study agency-based manifestations. They can be traced in a socio-psychological model of the ideal personality as a goal of the educational effects (a social demand on education - what subject a pupil has to become in the future and what social function he will exercise), an educational model of the ideal pupil (a state-educational demand on a school - what subject a pupil has to be during schooldays and what function he performs in an education institution), pedagogical characteristics of typical schoolchildren (a description of real schoolchildren - what subject a real pupil is, what functions he is allowed to perform in school and what he exercises at his discretion). Taking into account the above, agency indicators has been determined for every criterion. It refers to: a) an express практиці моделях організації освітнього процесу. Отримане знання належить до вироблення відповідних сучасним запитам стратегій розроблення освітніх інновацій, частиною яких є ідея самоорганізації суб'єкта учіння, його здатність до ефективного самовтілення в таких вимірах, як навчання, взаємо- та самонавчання, виховання, взаємо- та самовиховання, розвиток, взаємо- та саморозвиток.

Застосування інтерпретаційних стратегій, порівняльного та дискурс-аналізу забезпечило систематизацію динаміки змін у профілях суб'єктності вітчизняних школярів XX століття, а також виокремлення міри й характеру зв'язків між детермінантами, що зумовили розвиток і трансформацію ідеї суб'єктнісної спрямованості освітнього процесу як життєздатної та ефективної.

Кількісна оцінка прояву суб'єктності $є$ важливим, але допоміжним інструментом її діагностики. Тим більше, що категорія «суб'єктність» виходить із розуміння внутрішньо зумовлених процесів, оцінка яких у критеріях норми (відхилення в бік «+» чи «-») $є$ некоректною. y нашому дослідженні найоптимальнішим варіантом вивчення суб'єктнісних проявів став аналіз психолого-педагогічної характеристики школяра в наукових та навчально-методичних публікаціях (загальна кількість - 137 джерел) за визначеними критеріями й показниками. Їх можна простежити у соціально-педагогічній моделі ідеальної особистостіяк мети освітніх впливів (суспільний запит освіті - яким суб'єктом має стати школяр у майбутньому та яку функцію в суспільстві колись виконуватиме), освітній моделі ідеального школяра (державно-освітній запит школі - яким суб'єктом повинен бути школяр упродовж шкільних років і яку функцію в закладі освіти він виконує), педагогічних характеристиках типових учнів шкіл (опис реальних школярів - яким суб'єктом є реальний школяр, до яких функцій у закладі освіти він допущений, а які з них бере на себе без приписів). 3 урахуванням цього факту було визначено показники суб'єктності за кожним критерієм. Йдеться про: а) пряму вказівку на маркери суб’єктності (самостійність, інтенційність / ініціативність, креативність, свободу, відповідальність) 
indication of agency markers (independence, intentionality /initiative, creativity, freedom, responsibility) in the documents under examination (a personality model, model of an ideal pupil, characteristics of a real pupil synonyms which can be used for the description of independence, initiative, creativity, freedom, responsibility in the personal manifestations); b) the description of the functions close to agency markers but without naming of the very markers (a complete, limited or lacking set of agencybased functions of a pupil's personality). To evaluate the indicators, the author has applied a scale from +3 to -3 , where $+3-$ a marker name in a model or characteristics, $+2-$ a marker name substituted by synonyms, +1 - a fragmentary description of the functions of a marker without its direct naming, 0 - a lack of the indication of a marker or its functions, -1 - a fragmentary description of marker's dichotomy, -2 - the use of a synonymic row of marker's dichotomy, $-3-$ a name of dichotomy of a marker or its functions.

\section{Results}

The socio-cultural context of modern education is based on the need for schoolchildren's manifestation of self-activity, a capacity for selfregulated learning. Requirements they face under the framework of a mixed and distance learning stress the significance of a focus of the educational practice on promoting the idea of agency of a school community. Having regard to the beforementioned, agency should be considered as a backbone component of a new approach to being where everyone is defined as a reflexive agent, creator, implementer, organizer of one's life. In terms of the educational environment, the aforesaid is specified through the following markers: independence, initiative, responsibility, creativity, and freedom (Halian, 2017). In the author's opinion, they delve into the empirical parameters of identification of personal agency, among other phenomena, and elucidate its ontological essence.

To represent the development of the phenomenon under study, the author has created the profiles of a pupil's agency which draw up a role-based structure of his personality given a) the socio-historical situation during the $\mathrm{XX}^{\text {th }}$ century; b) worldviews reflected in the views of scientists, cultural figures у досліджуваних документах (моделі особистості, моделі ідеального школяра, характеристиці реального учня - якими синонімами можна послуговуватися для опису самостійності, ініціативності, креативності, свободи, відповідальності в особистісних проявах); б) опис функцій, наближених до маркерів суб'єктності, однак без указівки на самі маркери (повний, обмежений чи відсутній набір суб'єктнісних функцій особистості школяра). Для оцінювання показників було використано шкалу від +3 до - 3 , де +3 назва маркера в моделі чи характеристиці, +2 назва маркера, замінена синонімами, +1 - частковий опис функцій маркера без його прямого називання, 0 - відсутність вказівки на маркер або його функції, -1 - частковий опис дихотомії маркера, -2 - використання синонімічного ряду дихотомії маркера, -3 - назва дихотомії маркера або його функції.

\section{Результати}

Соціокультурний контекст сучасної освіти зав'язаний на потребі прояву школярами самоактивності, здатності до саморегульованого навчання. Вимоги, які постали перед ними в умовах змішаного, дистанційного навчання, підкреслили значущість орієнтованості освітньої практики на втілення ідеї суб'єктності учасників освітнього процесу. 3 огляду на це суб'єктність варто розглядати як системотвірний компонент нового підходу до буття, де кожного визнано рефлексивним агентом, творцем, реалізатором, організатором свого життя. Для освітнього середовища означене конкретизовано в таких маркерах: самостійність, ініціативність, відповідальність, креативність та свобода (Галян, 2017). Вони, на нашу думку, специфікують емпіричні параметри ідентифікації суб'єктності особистості з-поміж інших феноменів та розкривають її онтологічну сутність.

Для відображення розвитку досліджуваного явища нами створено профілі суб'єктності школяра, де специфіковано рольову структуру його особистості з огляду на а) суспільно-історичну ситуацію впродовж XX століття; б) світоглядні міркування, відображені в поглядах науковців, культурних діячів та педагогів; в) реалії освітнього середовища,

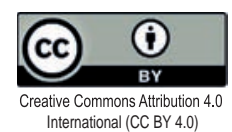


and educators; c) the realities of the educational environment the participants of the educational process belonged to. The scales of a profile are based on five markers of agency and their dichotomy: the "independence - dependence" scale, the "initiative - executive obedience (obedience)" scale, the "creativity - reproductivity (convergency, reactivity)" scale, the "freedom - hopelessness" scale, the "responsibility - an external determinacy".

Ukrainian political-ideological realities of the $\mathrm{XX}^{\text {th }}$ century have encouraged examining agency profiles in terms of five periods: 1) the early $X X^{\text {th }}$ century with its emphasis on the development of children's activity, creativity (1900 - 1917); 2) the period of the Ukrainian War of Independence (1917 - 1920) when self-active, responsible person was a priority; 3) the period of the experimental approach in pedagogical psychology and child-centrism (1920 - 1930); 4) formalization of the term of "allround man", orientation to the average indicators of schoolchildren's development (1930 - 1980); 5) renewal of the interest in a child's personality, his perception as a value (the 1990s).

Three profiles are differentiated under the specifics of agency manifestation:

- socio-personal - it renders the demands to a person as a representative of civilization, a participant of the social community (fig. 1);

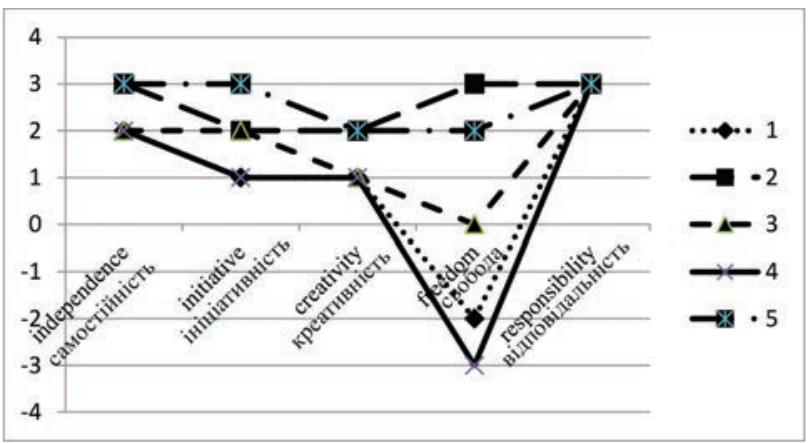

Fig. 1. Representation of agency markers in the sociopersonal profile of a domestic pupil in the $\mathrm{XX}^{\text {th }}$ century Рис. 1. Репрезентація маркерів суб'єктності в соціально-особистісному профілі вітчизняного школяра XX століття

Notes: periods of the XX ${ }^{\text {th }}$ century: 1 - 1900-1917; 2 $1917-1920 ; 3$ - 1920-1930; 4 - 1930-1980; 5 - the $1990 \mathrm{~s}$ Примітка: періоди XX ст.:1 - 1900-1917 рр.; 2 - 1917-1920 pp.; 3 - 1920-1930 рp.; 4 -1930-1980 рр.; 5 -1990-ті рр. у яких перебували учасники освітнього процесу. В основу шкал профілю закладено п'ять маркерів суб'єктності та їх дихотомії: шкала «самостійність - залежність», шкала «ініціативність - виконавчий послух (слухняність»), шкала «креативність - репродуктивність (конвергентність, реактивність»), шкала «свобода - приреченість», шкала «відповідальність - зовнішня детермінованість».

Політико-ідеологічні реалії України в XX столітті спонукали розглядати профілі суб'єктності в розрізі п’яти періодів: 1) початку $\mathrm{XX}$ століття з його акцентуванням на розвитку дитячої активності, творчості (1900 - 1917 рр.); 2) часу Визвольних змагань, коли пріоритетом визнавалась самоактивна, свідома особистість (1917 - 1920 рр.); 3) періоду експериментального підходу в педагогічній психології та дитиноцентризму (1920 - 1930 рр.); 4) формалізації поняття «всебічний розвиток особистості», орієнтуванням на усереднені показники розвитку школярів (1930 - 1980 рр.); 5) відродження уваги до особистості дитини, її сприймання як цінності (1990-ті рр.).

За специфікою прояву суб'єктності, диференційовано три профілі:

- суспільно-особистісний, у якому увиразнено вимоги до особистості як представника цивілізації, учасника соціальної спільноти (рис. 1);

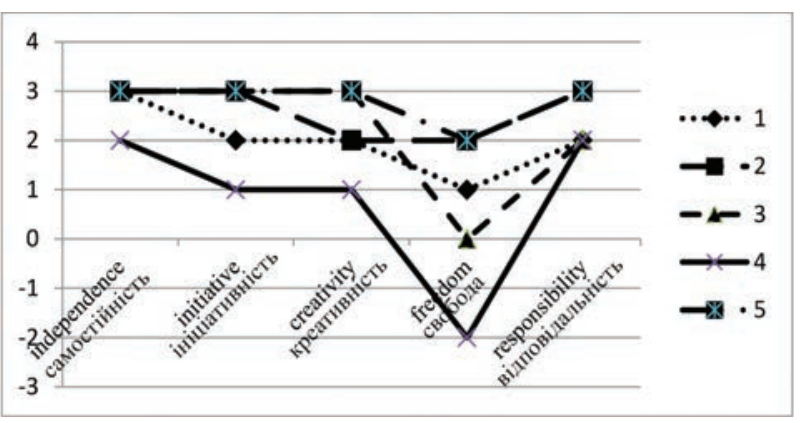

Fig. 2. Representation of agency markers in the educational-scientific profile of a domestic pupil in the $\mathrm{XX}^{\text {th }}$ century

Рис. 2. Репрезентація маркерів суб'єктності в освітньонауковому профілі вітчизняного школяра XX століття Notes: periods of the $\mathrm{XX}^{\text {th }}$ century: 1 - 1900-1917; 2 1917-1920; 3 - 1920-1930; 4 - 1930-1980; 5 - the 1990s

Примітка: періоди XX ст:1 - 1900-1917pp.; 2 - 1917-1920 pp.; 3 - 1920-1930 pp.; 4 - 1930-1980 pp.; 5 - 1990-ті рр. 
Development patterns of the idea of personal agency and its implementation in the domestic educational practice of the $\mathrm{XX}^{\text {th }}$ century

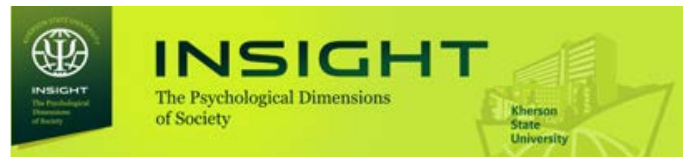

- educational-scientific - it describes the educational ideal at a particular stage of social advancement, a neurotypical level of development, the role characteristics of a pupil of a specific era (fig. 2);

- pupils' - it renders opportunities for the personal self-realization (fig. 3 )

Reconstruction of the dynamics of content, conditions for distinguishing the attributive features of agency, an institutional social role of a pupil during the $\mathrm{XX}^{\text {th }}$ century in the domestic educational discourse and environment has made it possible to formulate some patterns. They have established the interdependent processes of forming knowledge about a pupil under the dimensions of his agency. They are analyzed below.

1. The idea of a pupil's agency was developing in the pedagogical discourse against the background of the progress in learning the personal issues in psychology and philosophy. The $\mathrm{XX}^{\text {th }}$ century is characterized by a change of the scientific paradigm, which determined the priority to study the role of a man in society, his being as a reality. Thus, it was relevant to delve into the nature, factors, mechanisms and conditions of personal becoming, chiefly the agency's essence. In particular, a subject and agency were interpreted and became the fundamental categories of considering individual components in the concept of man, agency-activity approach, discourse of existence, personalism, and postmodern theories. Philosophicalpsychological analysis of a subject set new trends in examining a genesis of agency, opportunities for its advancement. The above influenced the expansion of a scientific search and its transfer into the dimension of the educational process. Consequently, an urgent character of creating psychological-pedagogical conditions, which would ensure the development of a pupil as a subject and his ability to explore reality not only adaptively but also creatively, showed a need to study the agency of a pupil as a pedagogical phenomenon by shifting the emphasis in the system of pedagogical interaction between an adult and a child. A humanistic direction, which emerged in psychology, outlined the opportunities for implementing its principles in education
- освітньо-науковий, що містить опис виховного ідеалу на конкретному етапі розвитку суспільства, нормотипового рівня розвитку, рольової характеристики школяра конкретної епохи (рис. 2);

- учнівський як відображення можливостей особистісної самореалізації (рис. 3).

Реконструювання динаміки змісту, умов вияву атрибутивних ознак суб'єктності, інституційованої соціальної ролі школяра впродовж XX століття у вітчизняному освітньому дискурсі й освітньому просторі дало змогу сформулювати низку закономірностей. Вони визначили взаємозумовлені процеси становлення знання про школяра у вимірах його суб’єктності. Розглянемо їх.

1. Ідея суб'єктності школяра в педагогічному дискурсі розвивалася у зв'язку з поступом в осмисленні особистісної проблематики в психології та філософії. Для $\mathrm{XX}$ століття характерна зміна наукової парадигми, що детермінувала пріоритетність дослідження питань ролі людини в соціумі, іï̈ буття як реальності. 3 огляду на це актуальним визнавалося вивчення природи, чинників, механізмів та умов становлення особистості, а особливо iï суб’єктної сутності. Зокрема, у концепції людини, суб'єктно-діяльнісному підході, екзистенційному дискурсі, персоналізмі, постмодерністських теоріях суб'єкт та суб'єктність

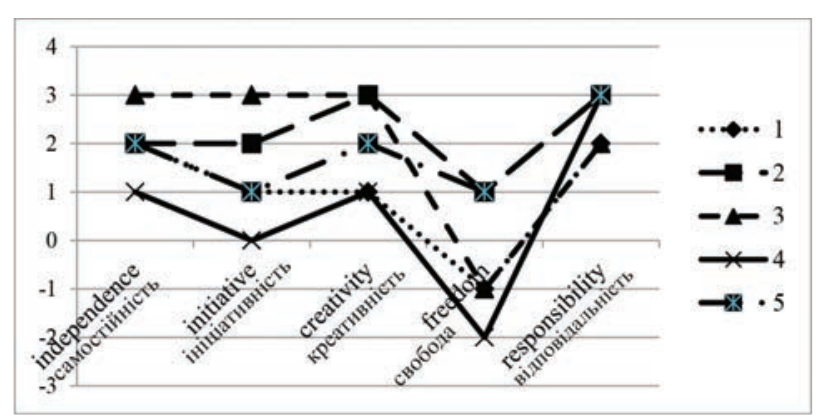

Fig. 3. Representation of agency markers in the pupils' profile of domestic schoolchildren in the $\mathrm{XX}^{\text {th }}$ century Рис. 3. Репрезентація маркерів суб'єктності в учнівському профілі вітчизняних школярів XX століття

Notes: periods of the $X^{\text {th }}$ century: 1 - 1900-1917; 2 -1917-1920; 3 -1920-1930; 4-1930-1980; 5 - the 1990s Примітка: періоди ХХ ст.:1 - 1900-1917pp.; 2 - 19171920 pp.; 3 - 1920-1930 pp.; 4 - 1930-1980 pp.; 5 - 1990-ті рр. 
and pedagogical activity. Their functions were grounded on the inherent value of a person and support of his drives for self-expression, selfdetermination and self-actualization.

2. Dependence of the development of the idea of a pupil's agency on the correlation of external and internal factors. A disputed attitude to the personal agency in view of its acceptance in socially approved forms and condemnation for an attempt to overstep the mark caused its ambiguous perception. In particular, there was heightened attention to the identification of agency and a need in its cultivation in the periods of democratic transformations (a time of the Ukrainian War of Independence (1917-1920), a situation of conserving an ethical identity for the West Ukraine (until 1939), approval of democratic principles of development of national education (since the 1990s)) and decrease in the days of ideological pressure. Consequently, the attitude to the agency of children and the youth was driven by the sociopolitical and socio-economic conditions, national and state building processes as the external factors of the development of the relevant idea and its extension to a pupil's personality.

At the same time, the logic of the generation of pedagogical knowledge (internal conditions), its reliance on accumulated facts, the statement of scientific problems, and the further development of available ideas allowed concluding the following: there was a transition from reductionism, heterogeneous perception of agency-related characteristics of the personality to a holistic one amidst the development of a pupil's agency. It is stated discreteness of the features of agency, their attribution to some (mainly allowed) areas of activity of a pupil and key tasks of a school (particularly, intellectual agency in the cognitive concept of a man) couldn't maintain a genuine agency. However, it became possible due to the methodological advancement in the context of poly-determinacy of personal activity and the focus on the realization of subject-agency cooperation. A personal approach was recognized to be actual along with an individual one.

The internal factors also encompass the impact of a foreign reform movement and progressive ideas on the evolution of the domestic pedagogical отримали своє тлумачення та стали засадничою категорію розгляду особистісного в людині. Філософсько-психологічний аналіз суб'єкта задав новий напрямок у дослідженнях ґенези суб'єктності, можливості її розвитку. Це, своєю чергою, вплинуло на розширення наукового пошуку та перенесення його в площину освітнього процесу. Відтак актуальність створення психолого-педагогічних умов, які б забезпечили розвиток школяра як суб'єкта та його здатності не тільки адаптивно, а й творчо пізнавати дійсність, визначила потребу дослідження суб'єктності учня як педагогічного феномена, водночас змістивши акценти в системі педагогічної співдії дорослого і дитини. А гуманістичний напрям, що зародився в психології, окреслив можливості реалізації його принципів в освіті та педагогічній діяльності. Адже їхні функції грунтувалися на самоцінності людини та підтримці ïi прагнення до самовираження, самовизначення та самоактуалізації.

2. Зумовленість розвитку ідеї суб'єктності особистості школяра взаємодією зовнішніх і внутрішніх чинників. Суперечливе ставлення до суб'єктності особистості з огляду на її прийняття в соціально схвалених формах та засудження за спробу виходу за "межі дозволеного" призвело до ï неоднозначного сприймання. Зокрема, спостерігаємо посилення уваги до вияву суб'єктності та потреби їі культивування в періоди демократичних перетворень (часи Визвольних змагань (1917-1920), у ситуації збереження власної етноідентичності для західноукраїнських земель (до 1939 р.), утвердження демократичних засад розвитку вітчизняної освіти (з 1990-х рр.)) та зниження в часи ідеологічного тиску. Отже, ставлення до суб'єктності дітей та молоді диктували суспільно-політичні та соціально-економічні умови, націо- та державотворчі процеси як зовнішні чинники розвитку означеної ідеї та їі екстраполяції на особистість школяра.

Водночас логіка становлення самого педагогічного знання (внутрішні умови), його опертя на накопичені факти, постановку наукових проблем, а також подальше розроблення попередніх ідей, уможливили висновок: у розвитку ідеї суб'єктності школяра 
theory and practice (freedom-based education, personality pedagogy). The early $\mathrm{XX}^{\text {th }}$ century and, after a while, the 1980s were characterized by a search for ways to implement child-centrism in terms of education and upbringing, overcoming formalism and dogmatism in a school by relying on the agency focus of pedagogical cooperation.

3. Heterochronism of the interpretative models of the personal agency of a pupil in the pedagogical ideal defined (more forced) by an educational policy and pedagogical concepts and theories, which were not formalized.

Development trends of the idea of a personal agency in the domestic pedagogical discourse of the $\mathrm{XX}^{\text {th }}$ century and tasks of a school to train the younger generation rendered high demands of the social practice. Thus, an orientation towards manufacturing requirements, facilitation of the scientific progress, cultural revolution and human-dimension of being set a goal of education and upbringing, forms and methods of their achievement. At the same time, preconditions for the realization of progressive ideas, a well-grounded standpoint on the renewal of education and organization of the educational cooperation, requirements for students and a training cooperation emerged at a socio-personal or scientific-pedagogical level outside an official education policy. It is typical that promulgated ideologemes could disharmonize with a pedagogical vision of a vector of changes in the school practice and professional views on the organization of the educational system of those scientists and educators who evaluated a pedagogical reality from the perspective of expediency and effectiveness.

4. Agency is not only substantial characteristics of a new (both postmodern and postnonclassical) personality. This ability is peculiar to a person as a subject of life activity regardless of an epoch. Therefore, the differences in an option of a pupil's manifestation of agency are determined by a predominant educational paradigm and technology for its activation. A contextual analysis of the domestic pedagogical discourse showed an agentless educational system, defining a child as an object of the pedagogical effects, had shaped before the $\mathrm{XX}^{\text {th }}$ century. Such a situation triggered protests of progressive teachers відбувся перехід від редукційного підходу, розрізненого сприймання суб'єктнісних характеристик особистості до холістського. Констатуємо, що дискретність ознак суб'єктності, їх віднесення до деяких (здебільшого дозволених) сфер діяльності школяра та провідних завдань школи (зокрема, інтелектуальна суб'єктність у когнітивній концепції людини) не могли забезпечити істинної суб'єктності. Проте це стало можливим завдяки методологічному поступу в розумінні полідетермінованості активності особистості, орієнтованості на реалізацію суб'єкт-суб'єктної співдії. Разом з індивідуальним підходом до школярів актуальним визнали й особистісний.

До внутрішніх чинників відносимо також вплив зарубіжного реформаторського руху i прогресивних ідей на розвиток вітчизняної педагогічної теорії та практики (вільне виховання, педагогіка особистості). Початок XX століття, а згодом і 1980-х рр. були позначені пошуками способів впровадження дитиноцентризму в навчанні та вихованні, подолання формалізму й догматизму в школі з опертям на суб'єктну спрямованість педагогічної співдії.

3. Гетерохронність інтерпретаційних моделей суб'єктності особистості школяра в окресленому (більше нав'язаному) освітньою політикою виховному ідеалі та педагогічних концепціях і теоріях, які не були формалізовані.

Тенденції розвитку ідеї суб'єктності особистості у вітчизняному педагогічному дискурсі XX століття, завдання школи в підготовці підростаючого покоління відбивали пріоритетні запити суспільної практики. Тому орієнтованість на потреби виробництва, забезпечення наукового прогресу, культурної революції чи людиновимірність буття окреслювали мету навчання та виховання, форми й методи їх здійснення. Водночас поза офіційною освітньою політикою на суспільно-особистісному або науково-педагогічному рівні виникали передумови для реалізації прогресивних ідей, аргументована позиція щодо оновлення змісту освіти та організації навчальної співпраці, вимог до вихованців та виховної співдії. Тому закономірно, що пропаговані ідеологеми могли дисонувати з педагогічним баченням вектору змін у шкільній практиці

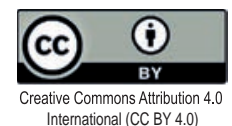


of that period who qualified agency as a natural expression of the individual features of children, their natural capacity for an adequate attitude to cognition. Their progressive ideas of children's activity and the need to stimulate it in specially provided conditions for research, creativity and independence contextually reflected the child-centered educational paradigm. As a result, it was individually developed within the pedological movement. However, a class-party program of education of the younger generation was formed in the USSR and centrally expanded to the domestic educational system, childcentrism was substituted for a knowledgecentric educational paradigm. "A smart school" (O. Muzychenko (Muzychenko, 1911)) conceded "a knowledge school"; a unitarian educational system, which favored only those manifestations of agency which face the dichotomy of an individual-social component to the benefit of social, collective (1930-1950), was prioritized on the long run. An intellectual agency of a personality of "education school" was given scientific credence in the theories of education and upbringing (H. Kostiuk (Kostiuk, 1989), Yu. Mashbyts (Mashbyts, 1988) et al.), and their developmental strategy contributed to working out the issues of the intensification of cognitive activity of schoolchildren, involvement of tasks according to a program and problems, and paying significant attention to intellectual independence. Personalized and differentiated approaches not only met demands of the tangible embodiment of the developmental education but also became a precondition for separating a personal aspect in schoolchildren's attitude to the content of the learned material, ways of acquiring knowledge, self-evaluationand self-revision during the educational-cognitive process. Gradually, "development school" expanded up to the "school of self-development" and the predominance of the humanistic educational paradigm in it. In spite the school preserved a traditional translational function and a priority of training ability, great importance was attached to the cooperation with the environment and independent comprehension of a new experience, responsibility for the decision made, and the act committed. The humanistic educational та професійними переконаннями щодо організації освітньої системи в тих науковців і педагогів, які оцінювали педагогічну реальність з позиції доцільності та ефективності.

4. Суб'єктність є не тільки змістовою характеристикою нової (і модерної, і постнекласичної) особистості. Ця здатність притаманна людині як суб'єкту життєздійснення не залежно від епохи. Тому відмінності вможливості вияву школярем суб'єктності визначені панівною освітньою парадигмою та технологією її активації. Контекстуальний аналіз вітчизняного педагогічного дискурсу показав, що ще до початку XX століття сформувалася безсуб'єктно орієнтована освітня система, яка визнавала дитину об'єктом педагогічних впливів. Така ситуація отримала протестну реакцію прогресивних педагогів цього періоду, які кваліфікували суб’єктність як природний вияв індивідуальних особливостей дітей, їхню природну здатність діяльного ставлення до пізнання. Запропоновані ними прогресивні ідеї щодо дитячої активності та потреби ії стимулювання в спеціально створених умовах дослідницької діяльності, творчості та самостійності контекстно відображали дитиноцентричну освітню парадигму. Відтак вона отримала свій розвиток у межах педологічного руху. Однак, коли класово-партійна програма виховання підростаючого покоління вибудувалася в СРСР і була централізовано поширена й на вітчизняний освітній простір, дитиноцентризм змінила знаннєвоцентрична освітня парадигма. «Розумна школа» (О. Музиченко (Музиченко, 1911)) поступилася «школі знання», на тривалий час визначилася пріоритетність унітарної освітньої системи, де заохочувалися лише ті прояви суб'єктності, у яких дихотомія індивідуального-соціального розв'язувалася з огляду на користь суспільного, колективного (1930-1950 рр.). Інтелектуальну суб’єктність особистості «школи навчання» науково обгрунтовано в теоріях навчання та учіння (Г. Костюк (Костюк, 1989), Ю. Машбиць (Машбиць, 1988) та ін.), а їх розвивальна стратегія сприяла розробленню питань активізації пізнавальної діяльності школярів, використанню в ній завдань за типом програмованих чи проблемних, а також зосередженню значної уваги на інтелектуальній самостійності. Індивідуалізований

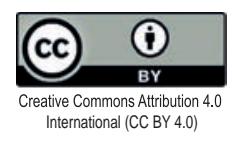


Development patterns of the idea of personal agency and its implementation in the domestic educational practice of the $\mathrm{XX}^{\text {th }}$ century

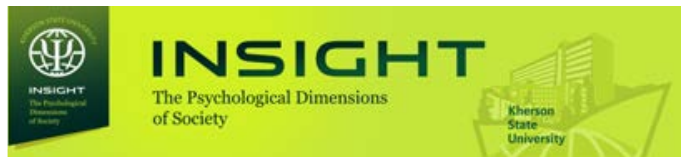

process contributed to the personalized focus of pedagogical technologies, a dialogue nature of pedagogical cooperation, and a human-centric attitude to schoolchildren. Consequently, the idea of agency was not only supported but also applied in some education institutions.

5. Pedagogic innovation always reflected the idea of priority of personal agency of a pupil as a result and a motivating factor in the organization of an effective pedagogical cooperation. In the early $\mathrm{XX}^{\text {th }}$ century, the above was demonstrated by the activities of private gymnasiums, as well as by experimental searches in the 1920s-1930s, conceptual approaches of innovative teachers of the 1960s-1980s, content of the activities of new types of educational institutions in the 1990s (gymnasiums and lyceums). Their orientation to education, upbringing and development of children and adolescents comprised the elements of cooperation, co-creation, co-search which, on the one hand, were based on individual characteristics of schoolchildren, their aptitude, abilities, and on the other - contributed to their growth. It is worth noting the innovative approach didn't always consciously (implicit knowledge) relied on the mechanisms of updating the intellectual and, in the research of educators of the 1990s, personal potential of schoolchildren, their ability to be involved in the creation of an environment for their self-development.

6. Agency established as an educational benchmark when a child's development gained equality in pedagogical science along with the processes of his education and upbringing. In addition to the historical background of the formation of pedagogy as a science, the author recognizes its orientation to rapprochement and the inseparable unity of education and upbringing. Being generalized in the scientific approaches, theories, concepts and technologies, they created a methodological space of the socio-humanistic knowledge of personality and forms, methods, and means for the organization of his education and upbringing. The trinity of pedagogical reality, such as teaching, education and development, made it possible to regard a pupil in terms of his agency.

\section{Discussion}

The $\mathrm{XX}^{\text {th }}$ century was a landmark for the understanding of a man as a subject through та диференційований підхід не тільки задовольняли запити практичного втілення розвивального навчання, а і стали передумовою виокремлення особистісного аспекту в ставленні школярів до змісту засвоюваного, способів привласнення знання, самооцінюванні та самоконтролі в навчально-пізнавальному процесі. Поступово «школа розвитку» розширилася до меж «школи саморозвитку», а згодом і панування в ній гуманістичної освітньої парадигми. Попри збереження в школі традиційної трансляційної функції та пріоритетність уміння вчитися, важливого значення надавалося співдії з оточенням та самостійному осмисленню нового досвіду, відповідальності за ухвалене рішення, здійснений вчинок. Гуманізований освітній процес забезпечив особистісну орієнтованість педагогічних технологій, діалогову природу педагогічної взаємодії, людиномірність ставлення до школярів. У такий спосіб ідею суб'єктності не тільки підтримано, а й у деяких закладах освіти було втілено.

5. Педагогічне новаторство повсякчас віддзеркалювало уявлення про пріоритетність суб'єктності особистості школяра як результату та спонукального чинника в організації ефективної педагогічної співдії. Це продемонстровано діяльністю приватних гімназій на початку XX століття, відтак експериментальними пошуками 1920-1930-х pр., концептуальними підходами педагогів-новаторів 1960-1980-х рр., змістом діяльності нових типів навчальних закладів у 1990-ті (гімназії та ліцеї). Їхня спрямованість на навчання, виховання та розвиток дітей і підлітків містила елементи співпраці, співтворчості, співпошуку, які, з одного боку, грунтувалися на індивідуальних особливостях учнів, їх нахилах, здібностях, а з іншого - сприяли їх розвиткові. Важливо, що не завжди усвідомлено (неявне знання) інноваційний підхід грунтувався на механізмах актуалізації інтелектуальної, а в пошуках педагогів 1990-х рр. - особистісної ресурсності учнів, іхній здатності бути залученими до творення середовища свого розвитку і самих себе.

6. Суб'єктність утвердилася як орієнтир освіти, коли в педагогічній науці одночасно з процесами навчання та виховання школяра паритетності набув його розвиток. Поза 
broadening the knowledge to the horizons of his agency-related essence, and later - at the beginning of the XXI ${ }^{\text {st }}$ century - to post-postmodern agency (Karpenko, 2006). The category of "agency" has acquired a content under the framework of its formal characteristics due to the interdisciplinary approach,particularlyphilosophical-psychological one (Roessler, Eilan, 2003). The above contributed to its interpretation in different social practices, including educational (Bałachowicz, 2009; Halian, 2017). Thus, it was launched a challenge against the previous education trends, and the research interest was aimed at updating the theoreticalmethodological fundamentals of the organization of the educational process (Kremen, 2014), justifying and conceptualizing the issues of childhood and methodology for its studying in the epoch of postmodern (Meynert, 2014). The present time, with its challenges, encourages scientists to look for interpretive strategies to come to grips with problems of the world (Kalischuk, 2020), its value, intellectual, creative and other parameters, the interaction with which changes a child (Lindgren, 2020), and refer to the difficulties in the training of a new generation.

In the author's opinion, a reference to the idea of personal agency makes it possible to define a road map for updating a system of psychological-pedagogical knowledge and progress in its realization in the context of educational institutions. Therefore, an outcome of the logical understanding of the nature of a man was rendered in the concepts which substantively revealed his potential ability to self-activity and assert the right to authorship and personal self-fulfillment. Domestic scientists show interest in the research of psychological patterns and mechanisms of these attributive characteristics of agency. Recent studies of the age-specific and socio-cultural factors have dealt with self-projection of personality (Chepelieva, 2016). By tracing the age-specific dynamics of this phenomenon, the emphasis is on the need for developing schoolchildren's ability to self-projecting, particularly in the middle childhood. According to the author, at that age "it is too early to speak of self-projecting as a conscious and purposeful process". It is also too early to speak of the authorship, which історичними аспектами становлення педагогіки як науки визнаємо iㅣ орієнтованість на зближення та нерозривну єдність навчання і виховання. Узагальнені в наукових підходах, теоріях, концепціях та технологіях, вони створили методологічний простір соціогуманітарного знання про особистість і форми, методи, засоби організації ії навчання та виховання. Триєдність педагогічної реальності як навчання, виховання та розвитку уможливила ставлення до школяра у вимірах його суб'єктності.

\section{Дискусія}

XX століття стало переломним для осмислення людини як суб'єкта, розширюючи це знання до горизонтів ії суб'єктнісної сутності, а згодом - на початку XXI ст. - пост-постмодерної суб'єктності (Карпенко, 2006). У своїх визначальних рисах категорія «суб'єктність» набула змістового оформлення завдяки міждисциплінарному підходові, особливо філософсько-психологічному (Roessler, Eilan, 2003), що уможливило ії витлумаченняу різних суспільних практиках, зокрема, освітній (Bałachowicz, 2009; Галян, 2017). Відтак було кинуто виклик попереднім тенденціям в освіті та спрямовано дослідницький інтерес наоновлення теоретико-методологічних засад організації освітнього процесу (Синергетика..., 2014), обгрунтування та концептуалізацію проблем дитинства та методології його вивчення в епоху постмодерна (Meynert, 2014). Сьогодення 3 його викликами спонукає науковців шукати інтерпретаційні стратегії для осмислення проблемностей світу (Каліщук, 2020), його ціннісних, інтелектуальних, творчих та інших параметрів, взаємодія з якими змінює дитину (Lindgren, 2020), апелювати до труднощів навчання дітей нового покоління.

На нашу думку, звертання до ідеї суб'єктності особистості дає змогу окреслити орієнтири змін в системі психолого-педагогічного знання та поступ у їі реалізації в умовах закладів освіти. Так, результат логічного осмислення суб'єктнісної сутності людини набув втілення в поняттях, які сутнісно розкривають їі потенційну здатність до самоактивності та відстоювання права на авторство й реалізацію своєї особистості. Вітчизняні дослідники демонструють зацікавленість дослідженням

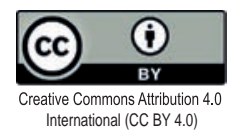


provides for creating the project "Self" (ib.); at the same time, it is stressed the possibility of learning to reinterpret life events through the special use of narrative techniques. This dimension is supplemented by studies on agency of preschoolers undertaken by Swedish scientists C. Caiman and I. Lundegård. The authors state children as "agents for change" are active participants in their own day-to-day practices. In the context of education for sustainability, it is essential what children achieve together rather than something they possess (Caiman, Lundegård, 2014). The beforementioned is complicated in the domestic educational practice by the following fact: a pedagogical reality is distinguished, on the one hand, by the progressiveness of views on the subject of learning, anticipation of his attitude to the understanding of environment and the effectiveness of self-organization during the training, and on the other - syncretism of the images of a real and ideal schoolchild that, in turn, can cause difficulties in implementing the pedagogical plan and solving professional problems by educators. Under these conditions, there is a relevance of the issue of becoming a pupil as a subject of learning, the search for those determinants and conditions under which he can realize his agency-related potential at different levels (mentally - physically, individually - socially, freely - in a determined way).

It's not much of a leap to understand special attention should be paid to the transformation of the educational process at the level of higher education, which a priori is based on the development of the future generation of educators capable of understanding the multidimensionality, self-organization and evolution of pedagogical reality where they stay and which will be a subject-matter of their future activity. The change of mental schemes of perception of pupils specially directed by the content and process of training and practice of self-realization of future teachers seems perspective (Halian, 2020; Tsiura, 2006; Räisänen, Postareff, Lindblom-Ylänne, 2016). That sort of standpoint is supported by a set of arguments: 1) under such conditions, it is possible to develop meta-competencies of students and, as proved by the author's previous research, to психологічних закономірностей i механізмів цих атрибутивних характеристик суб'єктності, Останнім часом дослідження вікових та соціокультурних чинників торкнулося самопроєктування особистості (Самопроєктування..., 2016). Простежуючи вікову динаміку цього феномену, закцентовано на потребі розвитку у школярів здатності до самопроєктування, зокрема, у молодшому шкільному віці. Як зазначили автори,у цьому віці “зарано говорити про самопроєктування як усвідомлений і спрямований процес. Зарано, говорити і про авторство, що передбачає створення проєкту "Я" (там само, С. 72), водночас наголошують на можливостях навчанню реінтерпретації життєвих подій за допомогою спеціального використання наративної техніки. Цей ракурс доповнюють дослідження суб'єктності дошкільників, проведені шведськими науковцями C. CaimantaI. Lundegård. Авторки стверджують, що діти, як “агенти змін" є активними учасниками власної повсякденної практики, і в умовах творення освіти для сталого розвитку суттєвим є не тільки те, що діти потенційно мають, а саме те, чого вони досягають у співдії (Caiman, Lundegård, 2014). Означене у вітчизняній освітній практиці ускладнює такий момент: педагогічну реальність вирізняє, з одного боку, прогресивність поглядів на суб'єкта учіння, антиципація його діяльнісного ставлення до пізнання довкілля та результативність самоорганізації в навчанні, а з іншого - синкретизм образів реального та ідеального школяра, що, своєю чергою, може спричиняти труднощі втілення педагогічного задуму та вирішення професійних завдань педагогами. У цих умовах знову постає питання становлення школяра як суб'єкта учіння, пошук тих детермінант та умов, за яких він стає здатним на різних рівнях (ментально - фізично, індивідуально соціально, вільно - детерміновано) реалізовувати свій суб'єктнісний потенціал.

Не важко зрозуміти, що особливої уваги потребує трансформація освітнього процесу на рівні вищої освіти, де апріорі закладено формуваннямайбутньої генерації педагогів, здатних усвідомлювати багатомірність, самоорганізацію та еволюцію педагогічної реальності, в якій

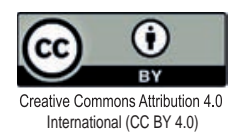


re-focus future teachers on finding the optimal combination of standardized educational goals and opportunities for personal selfdetermination of each participant in pedagogical cooperation (Halian, 2020). This is considered as an expected result of an updated educational design; 2) specially created educational situation encourages applicants to realize not only a logical, in their opinion, social role - "student", but also to evaluate their own experience of learning from the perspective of a social role - "a future teacher" (coincidence of a subject and an object of learning) (Shamrai, 2014: 277). Their contrast leads to the creation of "personal epistemology" (Brownlee, Ferguson, Ryan, 2017) towards understanding the methodology of future professional activity.

In this regard, the strategy of self-regulated education advantageously differs from others (Zimmerman, Schunk, 2011). A search for personal usefulness and a sense of everything that concerns life purpose of a person - today's student tomorrow's teacher" is a defining moment of selfidentity in this context (Tsiura, 2006: 5). In such a way, it is overcome "a repressive potential of education" (Shamrai, 1014: 266), its orientation to the "formation", and "standardization". It is proposed a holistic coverage of the fundamental aspects of the idea of agency in terms of its development that overpasses a simplified, mosaic vision of a child, an adolescent as a personality who can make own choice, create oneself and situation, identify the personal value and creatively influence an environment.

\section{Conclusions}

The issue of development patterns of the idea of the agency of a schoolchild in the domestic theory and education practice, an option of optimization of the educational practice relying on them has raised due to the contradictions in the two dimensions. On the one hand, there is a significant gap between scientific achievements in the agency-related area and the actual practice of education institutions, which have difficulties in the realization of one's agency by both students and teachers. On the other hand, an agency carrier - a student as a typical and an excellent representative of his epoch - doesn't fit in with вони перебувають та яка стане предметом їх майбутньої діяльності. Видається перспективною спеціально спрямована змістом і процесом навчання зміна мислесхем сприймання учнів та власна практика самовтілення майбутніх педагогів (Галян, 2020; Цюра, 2006; Räisänen, Postareff, Lindblom-Ylänne, 2016). На захист такого бачення можна навести низку аргументів: 1) за таких умов уможливлюється формування у студентів мета компетентностей i, як доведено нашими попередніми дослідженнями, переорієнтація майбутніх педагогів на віднаходження оптимального поєднання стандартизованих освітніх цілей та можливостей для особистісного самовизначення кожного учасника педагогічної співдії (Halian, 2020). Це вважаємо прогнозованим результатом оновленого освітнього дизайну; 2) спеціально створена освітня ситуація спонукає здобувачів реалізовувати не тільки логічну в їх розумінні соціальну роль -“студент", але й оцінювати власний досвід учіння з позиції соціальної ролі - "майбутній педагог”, (збіг суб'єкта та об'єкта пізнання (Шамрай, 2014: 277). Їх зіставлення спричиняється до творення "особистої гносеології” (Brownlee, Ferguson, Ryan, 2017) в осмисленні методології майбутньої професійної діяльності.

У цьому руслі вигідно вирізняється 3-поміж інших стратегія саморегульованого навчання (Zimmerman, Schunk, 2011). Поворотним моментом самоусвідомлення у цьому контексті можна також вважати «пошук особистої доцільності й сенсу, всього того, що стосується сенсів реального життя людини - сьогоднішнього студента - завтрашнього педагога» (Цюра, 2006: 5). У такий спосіб долається "репресивний потенціал освіти" (Шамрай, 1014: 266), iї орієнтованість на “формування", "нормативність" і пропонується холістичне схоплення засадничих аспектів ідеї суб'єктності у контексті її розвитку, що долає спрощене, мозаїчне уявлення про дитину, підлітка як особистість, яка здатна робити власний вибір, творити себе і обставини, визначати власну цінність та творчо впливати на середовище.

\section{Висновки}

Питання закономірностей розвитку ідеї суб'єктності школяра у вітчизняній теорії 
"a worldview and practices" of teachers who, in the author's opinion, need changing the paradigms of mental activity regarding substantive and procedural aspects of their own activities, as well as its results. Consequently, methodological pillars, which were an activity base of teachers in the $\mathrm{XX}^{\text {th }}$ century, should be reviewed given the scientific progress.

It is no surprise at all that the development of the idea of personal agency and its introduction in the practice of education institutions is caused by a complex system of determinants as it concerns, on the one hand, the realization of an education policy in a particular historical time, its focus on a social demand on a school and, on the other, a set of factors, such as the progress: a degree of scientific development of the issue of agency within the psychological and pedagogical knowledge; interdisciplinary links between humanities and joint crossdisciplinary research on the personal growth and personal self-realization; paradigmatic changes in the assessment of personal resources, the emergence of the humancentric vector of science development in general; use of a nonlinear approach to forecasting the outcome of cooperation, particularly, in the educational system.

Orientation to the sources of postnonclassical agency, evolution of this category in the scientific, educational and culturalhistorical discourse of the past allows working on a system-based strategy of its implementation in modern conditions of education, upbringing and development of schoolchildren. A focus, orientation and methodological vector of the idea of agency of a schoolchild's personality, its scientific validation, and socio-cultural maturity outline the substantive aspects of the idea-genesis of agency matters in the domestic discourse of the $\mathrm{XX}^{\text {th }}$ century. The analysis of actual educational practice in this period confirmed the influence of socio-historical, scientificpedagogical and pedagogical-technological phenomena on the opportunities of achieving agency self-realization by a student.

A variability of modeling activities of modern schoolchildren should become a defining feature of their education, upbringing and development. та освітній практиці, можливість оптимізації на їх основі сучасного освітнього процесу постало з огляду на ті суперечності, які спостерігаємо у двох площинах. 3 одного боку, існує значний розрив між науковими здобутками у царині суб'єктнісної проблематики та реальною практикою діяльності закладів освіти, де спостерігаємо труднощі втілення власної суб'єктності як учнями, так і педагогами. 3 іншого, носій суб'єктності - учень, як типовий і показовий представник своєї епохи, мало вписується в «картину світу і діяльності» педагогів, які, відповідно, потребують, на нашу думку, зміни схем миследіяльності щодо змістових та процесних аспектів власної діяльності, а також ії результатів. Таким чином, методологічні опори, які для педагогів кінця XX століття були основою діяльності, потребують переосмислення з урахуванням наукового поступу.

Закономірно, що розвиток ідеї суб'єктності особистості та її втілення в практику закладів освіти зумовлений складною системою детермінант, адже стосується, з одного боку, реалізації освітньої політики в конкретний історичний час, iї орієнтованості на суспільний запит школі, а з іншого - низкою чинників, як-от поступом: рівня наукової розробленості проблеми суб'єктності в межах психолого-педагогічного знання; міждисциплінарних зв'язків людинознавчих наук та спільних кросдисциплінарних досліджень з питань особистісного зростання й особистісного самовтілення; парадигмальних змін в оцінюванні особистісних ресурсів, появи людиновимірного вектору розвитку науки загалом; використання нелінійного підходу до прогнозування результатів співдії, зокрема, і в освітній системі.

Орієнтованість на джерела постнекласичної суб'єктності, еволюцію цієї категорії в науковому, освітньому та культурно-історичному дискурсі минулого уможливлює розроблення системної стратегії її втілення в сучасних умовах навчання, виховання та розвитку школярів. Спрямованість, орієнтація та методологічний вектор наповнення ідеї суб'єктності особистості школяра, iї наукова обгрунтованість, соціально-культурна зрілість окреслюють змістові аспекти ідеєгенезисуб'єктнісної 
Education institutions, which postulate that sort of approach, are open to innovations, the integration of various approaches, their approbation and selection of the most effective ones, stimulation and support of children's authorial searches and creative projects, their initiatives, creation of conditions for selfactivity and, thus, embodiment of true agency of participants of pedagogical cooperation.

\section{References}

Bałachowicz, J. (2009). Kategoria podmiotowości jako wyznacznik przemian stylu pracy współczesnego nauczyciela. In I. Adamek \& W. Żmijewska (Red.). Nauczyciel w systemie edukacyjnym teraźniejszość $i$ przyszłość (s. 12). Kraków: Wyd. nauk. UP.

Brownlee, J. L., Ferguson, L. E. \& Ryan, M. (2017). Changing teachers' epistemic cognition: new conceptual framework for epistemic reflexivity. Educational Psychologist. 52: 4, 242-252. DOI: $10.1080 / 00461520.2017 .1333430$

Caiman, C. \& Lundegård, I. (2014). Pre-school children's agency in learning for sustainable development. Environmental Education Research, 20:4, 437-459. DOI: $10.1080 / 13504622.2013 .812722$

Chepeleva, N. (Ed.) (2016). Self-design of personality in discursive space. Kyiv: Pedagogical thought.

Halian, O., Halian, I. \& Halian, A. (2020). Subject-matter competence in the field of psycho-pedagogy of agency as a resource of modernizing the content of higher pedagogical education. International Journal of Psychosocial Rehabilitation, 24:6, 1297612990. DOI: 10.37200/IJPR/V24I6/PR261268

Halian, I. (2020). Personal determinants of responsibility of future educators. Insight: the psychological dimensions ofsociety, 1,15-21.DOI:10.32999/2663970x/2019-1-2

Halian, O. (2017). Student personality in the dimensions of agency: historical and pedagogical discourse. Drohobych: Editorial and Publishing Department of Drohobych Ivan Franko State Pedagogical University.

Kalishchuk, S. (2020). Conceptualization of the existential system model of reorganization of the «worldview» of the personality: the introduction of ontological dominants. Insight: the psychological dimensions of society, 3, 11-27. DOI: $10.32999 / 2663-970 X / 2020-3-1$

Karpenko, Z. (2006). Cartography of integral agency: a post-postmodern project. In Human. Subject. Act: philosophical and psychological studies (pp. 157177). Kyiv: Lybid.

Kosyiuk, G. (1989). Educational process and mental development of personality. Kyiv: Radyanska shkola. проблематики у вітчизняному дискурсі XX століття. Аналіз реальної освітньої практики у цей період засвідчив вплив суспільно-історичних, науково-педагогічних та педагогічно-технологічних явищ на можливості досягнення школярем суб'єктнісної самореалізації.

Варіативність моделювання діяльності сучасних школярів повинна стати визначальною особливістю їх навчання, виховання та розвитку. Заклади освіти, де постулюється такий підхід, відкриті до інновацій, інтеграції різних підходів, їх апробації та вибору найрезультативніших, стимулювання й підтримки авторських пошуків і творчих проєктів дітей, їх ініціативи, створення умов для самоактивності, а отже, втілення істинної суб'єктності учасників педагогічної співдії.

\section{Список використаних джерел}

Bałachowicz, J. Kategoria podmiotowości jako wyznacznik przemian stylu pracy współczesnego nauczyciela. In I. Adamek \& W. Żmijewska (Red.). Nauczyciel w systemie edukacyjnym teraźniejszość i przyszłość (s. 12). Kraków: Wyd. nauk. UP. 2009.

Brownlee J. L., Ferguson L. E., Ryan, M. Changing teachers' epistemic cognition: of new conceptual framework for epistemic reflexivity. Educational Psychologist. 2017. Vol. 52. No 4. P. 242-252. DOI: 10.1080/00461520.2017.1333430

Caiman, C., Lundegård, I. (2014). Pre-school children's agency in learning for sustainable development. Environmental Education Research. 2014.Vol. 20. No 4. P. 437-459. DOI:10.1080/13504622.2013.812722

Самопроєктування особистості у дискурсивному просторі: монографія / за ред. Н. Чепелєвої. Київ: Педагогічна думка, 2016. 232 с.

Halian O., Halian I. \& Halian A.Subject-matter competence in the field of psycho-pedagogy of agencyasa resource of modernizing the content of higher pedagogical education. International Journal of Psychosocial Rehabilitation. 2020. Vol. 24, No 6. P. 1297612990. DOI: 10.37200/IJPR/V24I6/PR261268

Галян I. Особистісні детермінанти відповідальності майбутніх педагогів. Інсайт: психологічні виміри суспільства. 2020. № 1. С. 15-21. DOI:10.32999/2663-970x/2019-1-2

Галян О. Особистість школяра у вимірах суб'єктності: історико-педагогічний дискурс. Дрогобич: Редакційно-видавничий відділ Дрогобицького державного педагогічного університету імені Івана Франка, 2017. 360 с.

Каліщук С. Концептуалізація екзистенційносистемної моделі реорганізації «картини світу» 
Development patterns of the idea of personal agency and its implementation in the domestic educational practice of the $\mathrm{X} \mathrm{X}^{\text {th }}$ century

Kremen, V. (Ed.) (2014). Synergetics and education. Kyiv: Institute of the Gifted Child.

Lindgren, T. (2020). The figuration of the posthuman child Discourse: Studies in the Cultural Politics of Education, 41:6, 914-925. DOI: $10.1080 / 01596306.2019 .1576589$

Mashbits, E. (1988). Psychological and pedagogical problems of computerization of education. Moscow: Pedagogika.

Meynert, M. J. (2014). Conceptualizations of childhood, pedagogy and educational research in the postmodern: A critical interpretation. Lund University Department of Sociology / Division of Education. Lund.

Muzychenko, A. (1911). What is pedagogy and what does it teach? Public Encyclopedia of Scientific and Applied Knowledge, T. IX. Philosophy and Pedagogy / Kharkiv Society for the Dissemination of Literacy in the People. Moscow.

Räisänen, M., Postareff, L., \& Lindblom-Ylänne, S. (2016). University students' self- and co-regulation of learning and processes of understanding: a person-oriented approach. Learning and Individual Differences, 47, 281-288. DOI: 10.1016/j. lindif.2016.01.006

Roessler, J. \& Eilan, N. (Eds.). (2003). Agency and self-awareness: Issues in philosophy and psychology. New York: Oxford University Press.

Shamrai, V. (2014). Pedagogy as a practically and efficient consciousness. In V. Kremen (Ed.). Synergetics and creativity (pp. 266-279). Kyiv: Gifted Child Institute

Tsyura, S. (2006). Pedagogy of personal experience: a workshop for independent work. Lviv: Publishing Center of Lviv Ivan Franko National University.

Zimmerman, B. J., \& Schunk, D. H. (2011). Self-regulated learning and performance. An introduction and an overview. In B.J. Zimmerman \& D.H. Schunk (Eds.). Handbook of self-regulation of learning and performance (pp. 1-12). New York: Routledge.

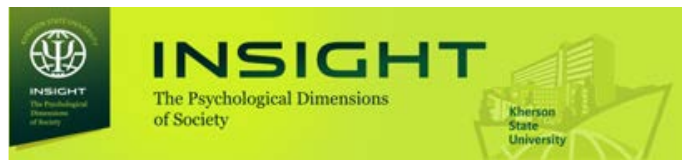

особистості: введення онтологічних домінант. Інсайт: психологічні виміри суспільства. 2020. № 3. C. 11-27.DOI: 10.32999/2663-970X/2020-3-1

Карпенко 3. Картографія інтегральної суб'єктності: пост-постмодерністський проект. Людина. Суб'єкт. Вчинок: філософсько-психологічні студіï. Київ: Либідь, 2006. С. 157-177.

Костюк Г. Навчально-виховний процес і психічний розвиток особистості. Київ : Рад. шк., 1989. $608 \mathrm{c}$.

Синергетика і освіта: монографія / за ред. В. Кременя. Київ: Інститут обдарованої дитини, 2014. 348 c.

LindgrenT. The figuration of the posthuman child Discourse: Studies in the Cultural Politics of Education.2020. Vol. 41. No 6. P. 914-925. DOI: 10.1080/01596306.2019.1576589

Машбиц Е. Психолого-педагогические проблемы компьютеризации обучения. Москва : Педагогика, 1988. 192 с.

Meynert M. J. Conceptualizations of childhood, pedagogy and educational research in the postmodern: A critical interpretation. Lund University Department of Sociology/ Division of Education.Lund, 2014. 168 p.

Музыченко А. Что такое педагогика и чему научитъ? Народная энциклопедия научных и прикладных знаний. T. IX. Философія и педагогика / Харьковское общество распространения в народграмотности. Москва, 1911. С. 134-181.

Räisänen, M., Postareff, L., \& Lindblom-Ylänne, S. Universitystudents' self- andco-regulation of learningandprocesses of understanding: a person-orientedapproach. Learningand Individual Differences.2016. Vol. 47. P. 281-288. DOI: 10.1016/j. lindif.2016.01.006

Agency and self-awareness: Issues in philosophy and psychology / J. Roessler, N. Eilan (Eds.). New York: Oxford University Press, 2003. 432 p.

Шамрай В. Педагогіка як практично-дієва свідомість. Синергетика i творчість: монографія / за ред. В. Кременя. Київ: Інститут обдарованої дитини, 2014. С. 266-279.

Цюра С. Педагогіка особистого досвіду: практикум для самостійної роботи. Львів: Видавничий центр ЛНУ імені Івана Франка, 2006. 185 с.

Zimmerman B. J. \&Schunk D. H. Self-regulated learning and performance. An introduction and anoverview. In B.J. Zimmerman\& D.H. Schunk (Eds.).Handbook of self-regulation of learning and performance. NewYork: Routledge, 2011. P. 1-12. 